A N N A L E S

UNIVERSITATIS MARIAE CURIE-SKŁODOWSKA LUBLIN - POLONIA

VOL. XXX, 1

SECTIO J

2017

Drohobych Ivan Franko State Pedagogical University, Ukraine

\title{
ZORJANA SPRYNSKA
}

zoriaspr@gmail.com

\section{Psychological Analysis of Value Sphere of Personality}

Psychologiczna analiza wartości osobowości

\begin{abstract}
SUMMARY
In the article the author analyzed peculiarities, regularities and problems of the nature of value sphere of modern youth. The links between value orientation indices and indices that explain the peculiarities of socialization of individuals were discovered. The strategies of psychological defense, needs, and psychosocial attitudes of modern youth were analyzed. It was established that the young of today choose aggression as a dominant strategy of psychological defense. The most prominent psychosocial attitude is freedom attitude.
\end{abstract}

Keywords: value; value importance; value accessibility; value orientations; needs; attitudes

\section{INTRODUCTION}

Problems associated with human values occupy one of the leading positions in the study of social determination of human behavior, its self-control and prediction. Value orientations play a crucial role in shaping the outlook, beliefs, choosing a life path as well as the regulation of behavior.

The dynamism of value sphere of a personality is explained by many different factors, amongst which the current situation in Ukraine (undeclared war) stands out the most. A number of current studies convince us that young people today appreciate only material values and lead a materialistic lifestyle (Filippovskyi 2010; Frolova 1998; Panina 2005; Skok 2002; Tytarenko 2003). Moreover, dis- 
tinguishing phenomena of declaring orientation into some values and true significance of orientation for an individual, we come across a conflict or confrontation. In numerous studies of value sphere of personality, we observe that the value "health" is in the forefront in the hierarchy of values and orientations on them (Butkivska 1997; Fantalova 2001). And it is well-known that this value is largely declared, because it acquires true value only for those who do not have it (health) (Sprynska 2014).

Today, important significance is acquired to values that are not described in popular methodologies for their diagnosis. For instance they are values of "peace" and "life" (human life as a value), which are dictated by current situation in the country and are true and not declared. Thus, we can speak about re-orientation of the individual's focus on spiritual values.

On the whole, the value is studied in two aspects: public and personal (Butkivska 1997). On the one hand, value means socially-significant concepts of what is good, justice, patriotism, love, friendship and more. On the other hand, it means the subject's relation towards objects and phenomena of reality, which is expressed by value orientations, social attitudes and personality traits. Here, they play the role of a certain personality structure. Values contribute to the transformation of social norms and ideals into individual principles of human life and continue to become an educational moment if they go into the intrinsic motives of the individual behavior. Value orientations represent a person's relationship to social reality and determine their behavioral motivation.

The source of the formation of value orientations is an important activity of the individual that determines the level of aspiration and orientation in the activities in order to achieve specific goals (Frolova 1998). The basis of value orientations make social (value) relations which are formed in the process of one's activities. Therefore, these relations then transform into social attitudes, and after a series of transformations - into value orientations.

Value orientations of a particular individual are formed and operate on the basis of value systems produced by society and are inextricably connected with it. In social and individual consciousness, values take on functions of life landmark, moral basis for the selection of one's occupation and subordination of their goals.

Value orientations are formed on the basis of individual's highest social needs in specific socio-historically caused forms of life (Butkivska 1997; Yadov 2013). They always meet the lifestyle of society and social group with which the individual identifies. As the outlook, ideology and way of thinking of the individual become the "reflection" of his socialization, then the main self-regulation of the individual's behavior is accomplished by this highest disposition level. 


\section{THE PROCEDURE AND METHODS}

The purpose of this research is to study the peculiarities of value sphere of personality and indicators associated with it. I conducted an empirical study, which was of psycho-diagnostic character. The investigation was conducted at the Ivan Franko National University of Lviv, Lviv State University of Life Safety, Drohobych Ivan Franko State Pedagogical University. The research involved 100 students aged $19-22$ years $(M=20.31 ; S D=1.074)$. These were 70 girls and 30 boys. They were students of such specialties as Economy, History, Foreign Languages, Ecology, Occupational Safety, Psychology, Social Pedagogy, and Preschool Education.

Methodological tools: methodology of "Value orientations" by M. Rokeach (1973), methods of diagnosing psychosocial attitudes of the individual in the field of need-motivational sphere by O. Potemkin, methods of diagnosing a dominant strategy of psychological defense in communication by V. Boyko, methods of diagnosing satisfaction levels of basic needs (Rajgorodskij [red.] 2009).

M. Rokeach's methodology in A. Fantalova's interpretation, unlike classical methodology, makes it possible to determine the system of value orientations of the individual by determining the degree of significance and availability of values (Fantalova 2001). Of course, significance does not mean attainability and vice versa, and, therefore, the discrepancy between significance and attainability may lead to inward discomfort, intrapersonal conflict and various mental conditions that have a negative effect on the mental health of the individual.

To diagnose the dominant strategy of psychological defense in communication, V. Boyko's methodology was used, in which the author offers the following strategies: peaceable disposition, avoidance, aggression (Rajgorodskij [red.] 2009).

O.F Potyemkina's methodology is aimed at identifying the degree of expression of the individual's social attitudes and mental sets in need-motivational sphere into "Altruism - Egoism", "Process - Result", "Freedom - Power", "Labor - Money".

The diagnostic technique used to determine the degree of satisfaction of basic needs is intended to determine the extent of satisfaction of certain needs (physical, social, security needs, recognition and self-expression) by comparing values to each other (Rajgorodskij [red.] 2009). Measures of satisfaction of needs: satisfied, partly satisfied, dissatisfied.

\section{THE ANALISIS OF RESULTS}

The results of the research have revealed the significance and accessibility of students' values. So, such values as a happy family life, love, health, a true 
friendship and material security are dominant for them. Values-outsiders: creativity, nature's beauty (Fig. 1).

A happy family life in the hierarchy of values takes the first place. It is natural for this age, though often a free lifestyle is promoted in modern media without taking any obligations on starting one's own family. Family sphere is a necessary element for successful functioning of personality. Self-realization in this sphere is a prerequisite for mental health.

The value of a happy family life is related with value of love. It is like a continuation of it or a logical completion. Youth dream about love expresses the need for emotional contact, understanding and spiritual closeness. Love is the need for selfless dedication, dissolution of a loving in care of a loved one.

The human's need to be healthy derives from the biological need for survival and security. Health is one of the highest human values. This statement is hard to argue, because the joy of life and the realization of life plans are impossible without it. As noted today the nation's health dramatically reduced in recent years so that is obviously that value of health is very important.

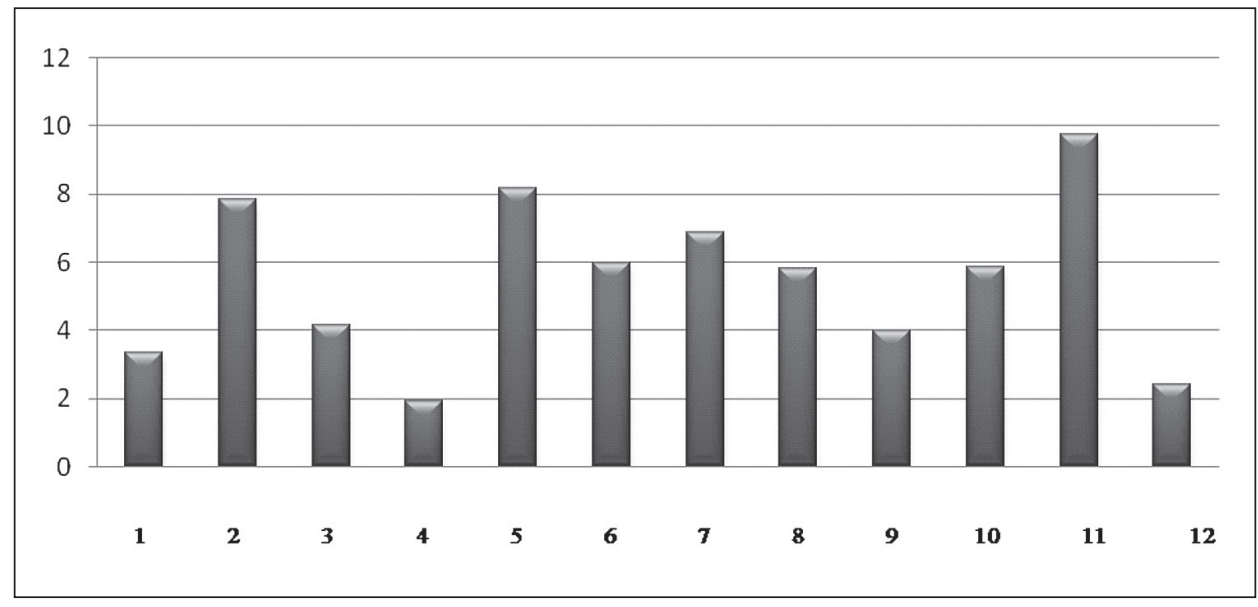

1 - Value of an active life, 2 - Value of health, 3 - Value of an interesting job, 4 - Value of nature's beauty, 5 - Value of love, 6 - Value of material security, 7 - Value of a true friendship, 8 Value of self-confidence, 9 - Value of knowledge, 10 - Value of freedom, 11 - Value of a happy family life, 12 - Value of creativity

Fig. 1. Indicators significance of values

Source: own work.

The hierarchy of availability values is headed by such values as love, health, a true friendship, freedom, self-confidence. The values of nature's beauty, creativity, an interesting work are the less available for young people (Fig. 2). 


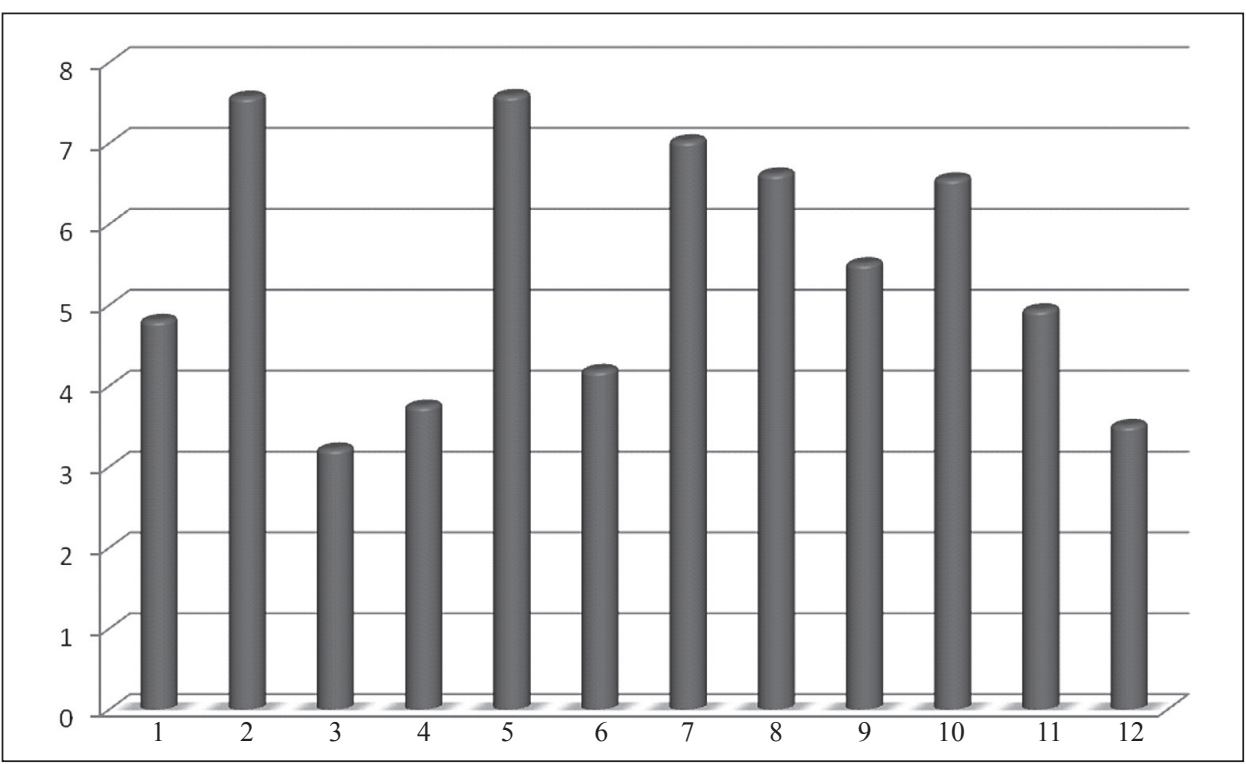

1 - Value of an active life, 2 - Value of health, 3 - Value of an interesting job, 4 - Value of nature's beauty, 5 - Value of love, 6 - Value of material security, 7 - Value of a true friendship, 8 Value of self-confidence, 9 - Value of knowledge, 10 - Value of freedom, 11 - Value of a happy family life, 12 - Value of creativity

Fig. 2. Indicators accessibility of values

Source: own work.

The lack of differences in the system of value orientations of the individual is important for achieving the state of inner peace and peace of mind. The study of value orientations in the light of their importance and availability suggests a certain intrapersonal conflict. Conflict of value orientations can also be divided into two groups - those with value greater than attainability, and those with greater attainability over value. Of course, the indicator of differences in the system of values where value is greater than availability is more important, since it is this discrepancy that can cause a feeling of inward mental anxiety, mental disorders such as depression (Sprynska 2014).

The biggest difference between the importance and the availability of values is detected among values of a happy family life, material security and an interesting job (Fig. 3). 


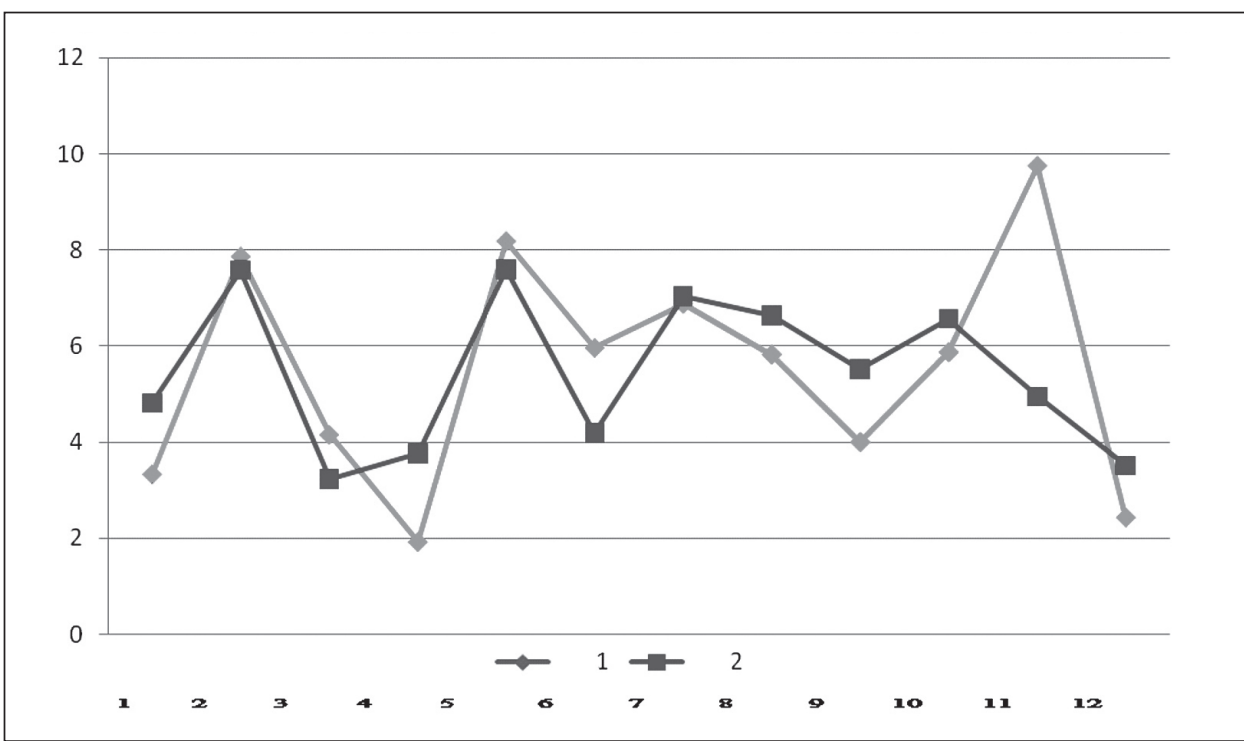

1 - Value of an active life, 2 - Value of health, 3 - Value of an interesting job, 4 - Value of nature's beauty, 5 - Value of love, 6 - Value of material security, 7 - Value of a true friendship, 8 Value of self-confidence, 9 - Value of knowledge, 10 - Value of freedom, 11 - Value of a happy family life, 12 - Value of creativity; row 1 - the significance of values, row 2 - the accessibility of values

Fig. 3. Indicators significance and accessibility of values

Source: own work.

A happy family life is the most "conflict" value. This can be explained by the fact that most of the students live in the dorms - and this leads to a lack of family warmth and presence of friends (by the way, one of the most available value) cannot fully compensate for the deficiency of family. Also, this age is a period for starting one's own family, but not everyone has that value. In addition, young people are "not satisfied" with their financial situation (importance much outstrips availability). The discrepancy between the importance and availability of values is a factor that explains an internal conflict of personality.

So the portrait of the young generation is quite controversial. On the one hand, they are romantic people who appreciate a family life, true friendship and mutual love very much. On the other hand, they are strict pragmatists who value their health and financial well-being.

The following correlations were revealed in the application analysis (Pearson's $r)$. The substantive positive ties were between the indexes ( $\mathrm{p} \leq 0.01)$ : Altruism and Peaceableness, Egoism and Aggression, Freedom and Aggression, Freedom and Result, Power and Aggression, Power and Result, Power and Freedom, Money and Result, Money and Power, the Need for material satisfaction and Ego- 
ism, the Need for material satisfaction and the Need for safety, Social needs and Peaceableness, Value of material security and Egoism, Value of confidence and Escape, Value of knowledge and Value of nature's beauty, Value of a happy family life and Value of love, Accessibility of value of health and Value of health, Accessibility of nature's beauty and Value of an interesting job, Accessibility of love and Value of material security, Accessibility of a true friendship and Accessibility of love, Accessibility of self-confidence and Value of freedom, Accessibility of knowledge and Value of knowledge, Accessibility of knowledge and Accessibility of nature's beauty, Accessibility of freedom and Accessibility of self-confidence, Accessibility of creativity and Value of creativity.

Less significant positive connections were between the indicators $(p \leq 0.05)$ : Result and Process, Labor and Process, Freedom and Egoism, Power and Egoism, Money and Aggression, the Need for material satisfaction and Money, Social needs and Altruism, Value of health and the Need for material satisfaction, Value of an interesting job and Peaceableness, Value of love and Altruism, Value of love and Labor, Value of material security and Escape, Value of material security and Money, Value of health and Altruism, Value of health and Value of self-confidence, Value of a happy family life and Value of a true friendship, Value of creativity and Labor, Accessibility of an active life and Peaceableness, Accessibility of an active life and Value of an active life, Accessibility of an active life and Value of an interesting job, Accessibility of an active life and Value of a happy family life, Accessibility of health and Escape, Accessibility of health and the Need for security, Accessibility of self-confidence and Value of self-confidence, Accessibility of knowledge and Accessibility of confidence, Accessibility of freedom and Value of freedom, Accessibility of creativity and Accessibility of knowledge.

Significant negative correlations were between the indexes $(\mathrm{p} \leq 0.01)$ : Escape and Peaceableness, Aggression and Peaceableness, Aggression and Escape, Egoism and Peaceableness, Egoism and Altruism, Power and Peaceableness, Social needs and Aggression, Social needs and Egoism, Personal needs and Power, the Need for self development and the Need for material satisfaction, the Need for self development and Security, Value of material security and Altruism, Value of a true friendship and Value of material security, Value of self-confidence and Peaceableness, Value of self-confidence and Value of material security, Value of knowledge and Value of love, Value of freedom and Value of love, Value of a happy family life and Value of nature's beauty, Value of creativity and Value of self-confidence, Accessibility of health and Value of freedom, Accessibility of nature's beauty and Result, Accessibility of self-confidence and the Need for security, Accessibility of self-confidence and Value of creativity, Accessibility of knowledge and Accessibility of material security, Accessibility of freedom and the Need for safety, Accessibility of a happy family life and Accessibility of nature's beauty, Acces- 
sibility of a happy family life and Accessibility of knowledge, Accessibility of a happy family life and Accessibility of freedom, Accessibility of creativity and Value of self-confidence.

Less significant negative correlation were between these indexes $(p \leq 0.05)$ : Altruism and Aggression, the Need for material satisfaction and Altruism, the Need for safety and Result, the Need for self development and Escape, Value of an active life and Result, Value of health and Labor, Value of nature's beauty and Value of health, Value of love and Value of nature's beauty, Value of material security and Value of health. Value of a true friendship and Value of an active life, Value of knowledge and Value of an interesting job, Value of knowledge and Value of a true friendship, Value of freedom and Labor, Value of freedom and Value of an interesting job, Value of a happy family life and the Need for material satisfaction, Value of creativity and Value of freedom, Accessibility of love and Value of health, Accessibility of love and Accessibility of an interesting job, Accessibility of love and Accessibility of nature's beauty, Accessibility of material security and Peaceableness, Accessibility of a true friendship and Value of nature's beauty, Accessibility of self-confidence and Accessibility of health, Accessibility of freedom and Altruism, Accessibility of a happy family life and Process, Accessibility of a happy family life and Accessibility of an active life, Accessibility of creativity and Accessibility of a happy family life.

Correlation analysis of the studied indices showed the presence of numerous relationships between value orientation indices and indicators that explain the peculiarities of socialization of a personality (psychological defense strategies, needs, psychosocial attitudes). So let us proceed with the analysis of indicators that are associated with value orientations.

Thus, $47 \%$ of today's youth chooses aggression as a dominant strategy of psychological defense (defense strategy of subjective reality of personality, which is instinctive) (Fig. 4). According to gender criterion, $45 \%$ of girls and $50 \%$ of boys belong to it (Fig. 5). This explains the undeniable fact that aggression does not come from the repertoire of emotional responses. Its powerful energy protects the "self" of the individual in the crowd, on the street, in public transport, in line, at work, at home, in relationships with strangers and very close people.

In recent years, we can observe the growth of aggressive activity in its various manifestations. Thus, the meaning of aggression is extremely high; its positive function allows directing the activity of the individual in the right direction. But today's society, through variety of ways (including the media), on a daily basis demonstrates the efficiency and effectiveness of negative aggression in various spheres of human existence. Thus, it can be said that society justifies it, makes it socially legitimate. The analysis of information obtained through the media proves that the use of aggression is a typical and effective way of obtaining what is desired. The individual can protect what is important and of value to him, and 
he can do it aggressively. If it is not possible to choose a different constructive solution to the problem, why not use aggressive strategy, which for sure is effective. Mastering such model of psychological defense happens very fast (Bandura, Walters 1959, 2000; Bandura, Ross, Ross 1961), because protecting your own beliefs using aggression is the easiest and most effective way.

Socio-economic crisis of the society has led to a number of problems, provoking people to use force to solve them. Aggressive acts come as a means of achieving any meaningful goal. But the problem is that the efficacy of aggressive manifestations in achieving certain goals caused deformation in the regulation of aggressive behavior of a modern individual, for instance, they put them on the path of destruction, and not on the path of positive aggression (activity).
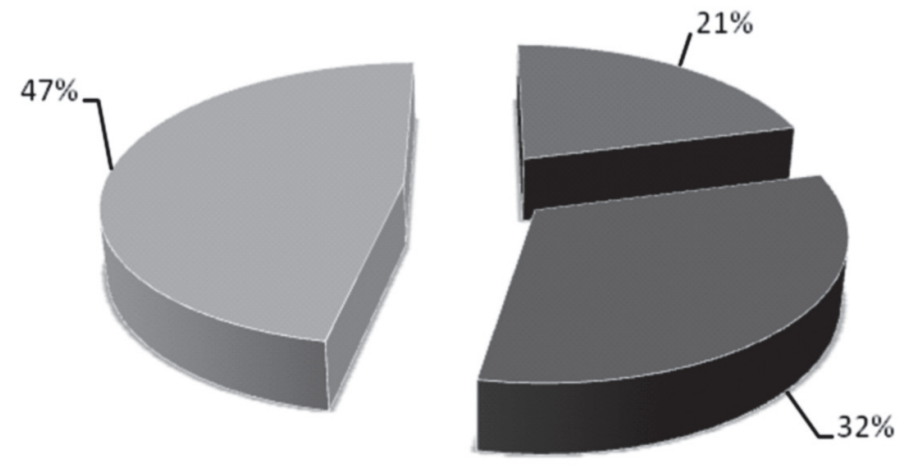

$=1=2=3$

1 - peaceableness, 2 - escape, 3 - aggression

Fig. 4. Indicators of dominant strategy of psychological defense

Source: own work.

$32 \%$ of surveyed individuals consider avoiding as a dominant strategy of psychological defense, as it is a way of protecting subjective reality, based on savings of intellectual and emotional resources ( $29 \%$ of girls and $35 \%$ of boys). They usually avoid or leave places of conflict and stress, when their "self" is exposed to attacks. However, these individuals do not waste their emotional and intellectual energy. 


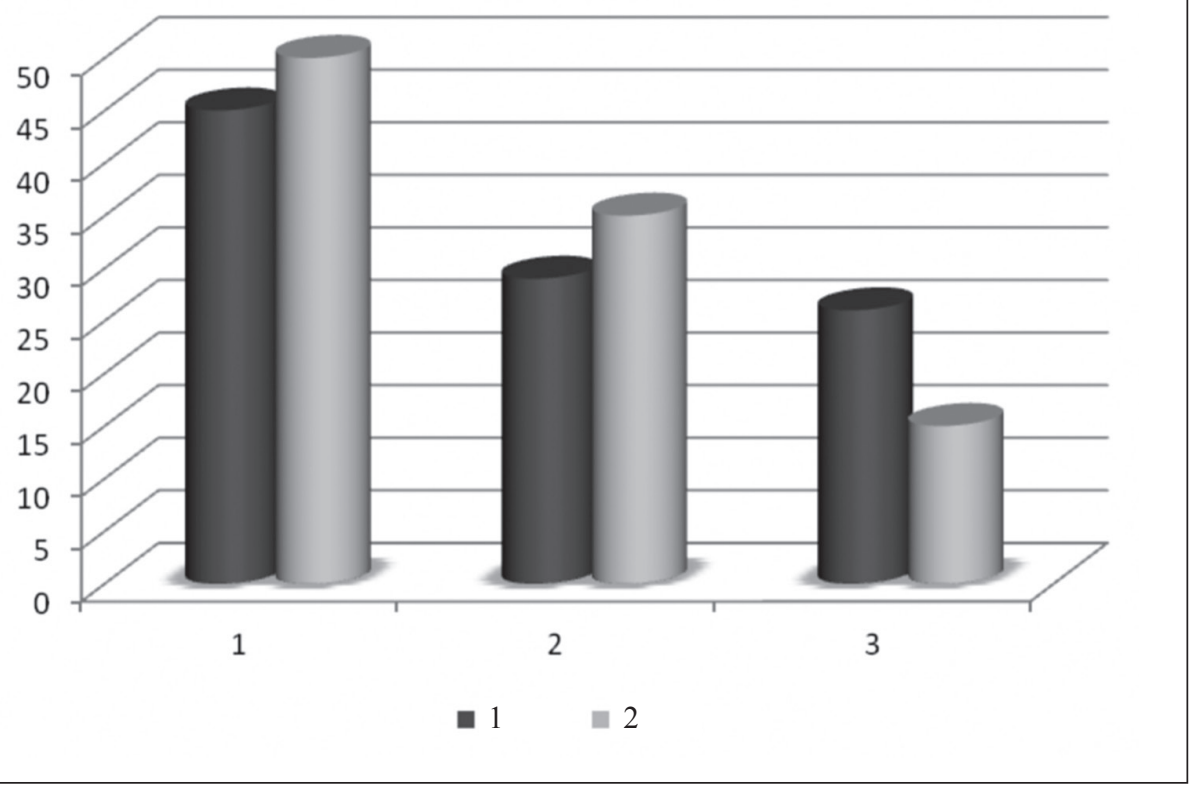

1 - aggression, 2 - escape, 3 - peaceableness; row 1 - indicators of girls, row 2 - indicators of boys

Fig. 5. Indicators of dominant strategy of psychological defense of girls and boys Source: own work.

And only $21 \%$ of young people choose peaceableness, as a strategy of psychological defense ( $26 \%$ of girls and $15 \%$ of boys). Peaceable disposition provides for partnership and cooperation, ability to compromise, to make concessions and be flexible, which is a more typical psychological defense strategy for females. In some cases peaceable disposition means adjustment, the desire to make concessions, not to aggravate relations and not to get involved in conflicts to avoid subjecting their "self" to a tThus, from the foregoing methods of psychological defense, aggression manifests itself as a primary activity overall capacity, dedication and expediency of activities to meet the challenges of adaptation, support and development of their self-identity (courage, willpower, ambition, perseverance, courage).

Regarding the analysis of psychosocial attitudes of young people (Fig. 6), the most pronounced methodology, amongst all other proposed by the author, is freedom attitude. Freedom for today's youth is the main value that does not tolerate any restrictions and it (the youth) is ready to make sacrifices to defend their independence. Freedom defines and provides a person with the opportunity to act according to their own will. The value of freedom is that it is present only when 
no external determinants of human exposure are present, when their actions are determined by internal factors and motives; when their aim is the greatest possible satisfaction of needs (desires) and most of all those vital ones. It should be noted that modern youth sometimes misinterprets the concept of freedom (freedom - is peace, end of war; it is a choice, the lack of coercion from other people; it is a free expression of their personality, their interests, thoughts; freedom from a global perspective does not exist, one always depends on something) (Sprynska 2014).

In other words, freedom, on the one hand, signifies independence and choice, and on the other hand, a non-existent concept, as there is always dependency on something. Freedom manifests itself not only as choices, but also as a possibility to choose that depends on objective social conditions, as well as on the person's realization of this possibility and their desire to make a certain choice.

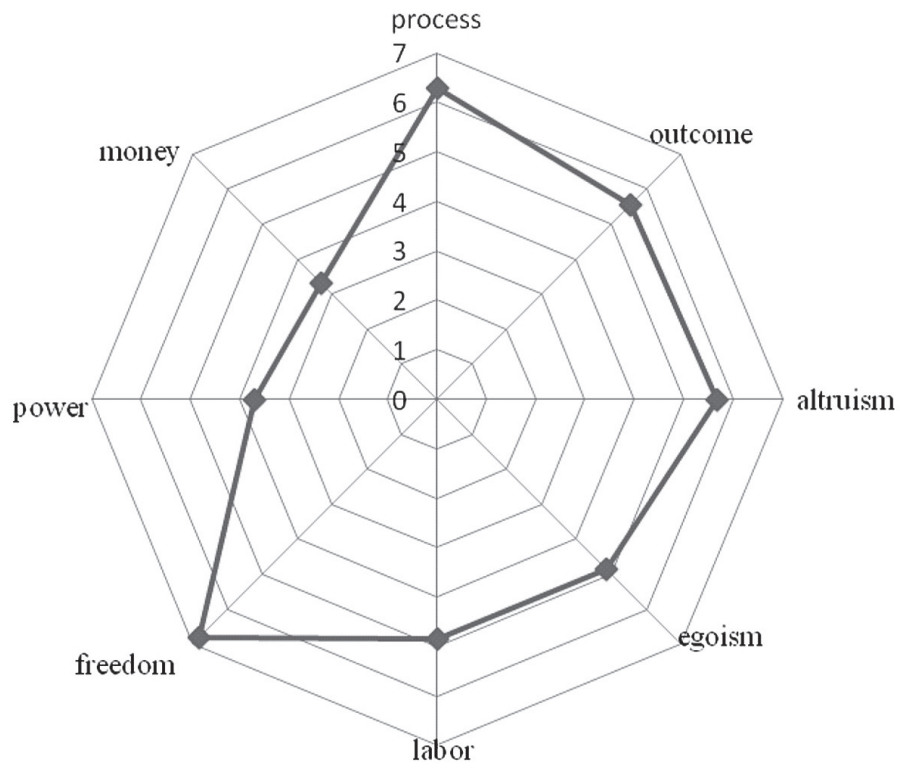

Fig. 6. Indicators of psychosocial attitude Source: own work.

Also young people pay great attention to the process, that being said, it is important for the subjects when the activity is interesting. Few of them may think about achieving their goals (their procedural orientation interferes with their performance; they are drawn more by the interest to the case). But it is easier for youth with such attitude to cope with tasks, where the process is of utmost importance. 
The majority of young people who partook in our study have altruistic sets rather than egoistic. Altruism is the most valuable public motivation, the presence of which defines a mature person. The dominance of altruism can also be explained by current situation in the country which strengthened volunteering, that is helping participants, victims of ATO and their families.

As for settings such as "work and money", then youth prefers to work, which means they need to provide for themselves and work is their means for existence, work serves as a means of realizing other needs that may be beyond the work itself.

Comparative analysis of psychosocial attitudes of girls and boys shows that girls have more pronounced focus on work. The boys show more pronounced egoism in comparison with altruism. When making decisions, boys quite seriously consider the impact of consequences and the result of their decisions on them.

Analysis of the degree of satisfaction of basic needs of the individual shows that $23 \%$ of today's youth consider themselves financially secured, $57 \%$ consider themselves partly secured and $20 \%$ want better financial security. The need for security is basic and is aimed at preserving human species and comfort in society, where the latter, unfortunately, is missing now. Thus, $15 \%$ of respondents are dissatisfied with this need, $62 \%$ of people are partly satisfied with it and $23 \%$ of young people are completely satisfied. It should be noted that the degree of need for security is much higher in girls than boys.

Man by nature is inclined to look for interpersonal contacts with others; therefore, satisfying social needs is equally important. Interpersonal interaction is necessary to: assert own "self", to understand one's own place in society; to avoid self-doubt; to receive a positive stimulus by means of interesting interactions; to receive attention and praise from others; to get emotional support; to form a selfconcept; to share skills, knowledge, experiences and results of activities; to influence the milieu. Only $16 \%$ of those under study are content with this social need, $67 \%$ are partially satisfied and $17 \%$ are dissatisfied.

The need for respect, satisfaction of human vanity (awareness of personal achievement, competence and recognition of others) is satisfied in $22 \%$ of subjects, partly satisfied in $70 \%$ of them, and $8 \%$ of respondents are dissatisfied. Satisfaction of being respected calls forth self-confidence, feeling of usefulness, value, strength and recognition of one's own abilities and useful results that people need so much to achieve the desired. Obstacles in realization of needs of selfrespect lead to the feelings of inferiority, weakness and helplessness.

Self-expression is the embodiment of one's inner world in the external world; it is a manifestation of one's ideas in the material world, based on one's individual world-view. According to K. Abulkhanova-Slavskaia and T. Berezina, selfexpression is a way with the help of which a person tries to express him/herself as an individual in activities communication, in solving life's problems (Abulkhanova- 
-Slavskaia, Berezina 2001). According to E. Fromm, in modern technocratic society one can observe strict restrictions in self-expression (Fromm 1992). Hence, such tendency leads to frustration and dissatisfaction with life.

Thus, $25 \%$ of today's youth have unmet the need for self-expression, that is, they cannot express themselves as individuals in various spheres of human existence. In $62 \%$ of young people this need is partially satisfied, in other words, they strive for the utmost self-disclosure, the use of their knowledge and skills, the accomplishment of their own ideas, the realization of individual talents and abilities, they want to achieve all desired and to be better and feel self-satisfaction. This need for self-expression is the highest of all human needs. And only $13 \%$ of young people have completely satisfied self-expression need, they can fully express their own individuality.

\section{CONCLUSION}

Hence, we can say that physical, social, safety, esteem and self-expression needs are partially satisfied. Partially unmet needs of today's youth are closely associated with their life prospects. Such plans are not organized, systematized. They change in due course, get adjusted depending on many circumstances (and directly with the present situation in the country) that can be called human life experience.

The results of the study assert that the value sphere of a modern youth is characterized by incompleteness and inclination for transformation under the new life circumstances, accompanied by the process of further value and motivational selfdetermination, further selection of moral, social and spiritual value orientations.

A person's life plans to occupy certain social position in society, are linked to desire, allowing him/her to satisfy his/her needs for self-realization. Social position, in its turn, is a key factor that determines a person's way of life, their behavior, actions and deeds, which means that young people's life plans and needs determine their value orientations.

Young people enter adult life with big plans and ideas, but without sufficient experience, without being ready to overcome obstacles on the way to fulfill their goals, needs. Value disparities and their availability is a factor that triggers intrapersonal conflicts. Therefore, the development of ways of forming all components of value sphere of personality at school must be the prospect of future studies. 


\section{REFERENCES}

Abulkhanova-Slavskaia K., Berezina T. (2001), Vremja lichnosti i vremja zhizni, Saint- Petersburg: Alteia.

Bandura A., Walters R. (1959), Adolescent Aggression, New York: Ronald Press.

Bandura A., Walters R. (2000), Podrostkovaja agressija: Izuchenie vlijanija vospitanija i semejnyh otnoshenij, Moskva: OOO Aprel'-Press.

Bandura A., Ross D., Ross S. (1961), Transmission of aggression through imitation of aggressive models, "Journal of Abnormal and Social Psychology", Vol. 63(3),

DOI: https://doi.org/10.1037/h0045925.

Butkivska T. (1997), Problema tsinnostei u sotsializatsii osobystosti, [in:] O. Sukhomlynska (red.), Tsinnosti osvity $i$ vykhovannia, Kyiv.

Fantalova E. (2001), Diagnoatika i psihoterapija vnutrennego konflikta, Samara: BAKHRAKX-M.

Filippovskyi V. (2010), Tsinnisni oriientatsii v kulturi osobystosti studenta, http:/h.ua/ story/276824/\#ixzz4iYjmm0DL (access: 10.02.2017).

Frolova N. (1998), Transformatsiia systemy tsinnisnykh oriientatsii na zlamnykh etapakh rozvytku suspilstva (psykholohichnyi aspect), Extended abstract of candidate's thesis, Kyiv.

Fromm E. (1992), Chelovek dlja sebja; issledovaniie psihologicheskih problem jetiki, Minsk: Kollehium.

Panina N. (2005), Ukrainske suspilstvo. 1994-2005. Sotsiolohichnyi monitorynh, Kyiv: Sofiia.

Rajgorodskij D. (red.) (2009), Prakticheskaja psihodiagnostika. Metodiki i testy, Samara: BAKHRAKH-M.

Rokeach M. (1973), The Nature of Human Values, New York: Free Press.

Skok M. (2002), Tsinnisni oriientatsii osobystosti suchasnoho studenta.

Sprynska Z. (2014), Psykholohichna kharakterystyka tsinnostei molodi cherez pryzmu yikh znachymosti ta dostupnosti, [in:]. Nauka sohodni. Propozytsii-Science Today. Offers: Proceedings of the International Conference, Part 6, Warsaw: Diamond trading tour.

Tytarenko T. (2003), Zhyttievyi svit osobystosti: u mezhakh I za mezhamy budennosti, Kyiv: Lybid. Yadov V. (2013), Samoreguliacija i prognozovanie socialnogo povedenija lichnosti: Dispozitsionnaja konceptsija, Moskva: CSPiM.

\section{STRESZCZENIE}

W artykule przeprowadzono analizę osobowości oraz problemu sfery wartościowania współczesnej młodzieży. Znaleziono związek między wskaźnikami orientacji wartościujących i wskaźnikami, które tłumaczą procesy socjalizacji osobowości. Przeprowadzono ponadto analizę strategii ochrony psychologicznej, potrzeb i socjalno-psychologicznych postaw młodzieży. Ustalono, że współczesna młodzież w komunikacji wybiera agresję jako dominującą strategię ochrony psychologicznej. Z kolei dominującą postawą socjalno-psychologiczną jest postawa na wolność.

Słowa kluczowe: wartości; znaczenie wartości; dostępność wartości; orientacja wartościująca; postawy; potrzeby. 